\title{
Aneurysm of the inferior thyroid artery
}

\author{
V. Seenu, S. Baliga and M.C. Misra
}

Department of Surgical Disciplines, All India Institute of Medical Sciences, New Delhi, 110029, India

Summary: A case of aneurysm of the inferior thyroid artery is presented. It is usually not possible to diagnose the exact site of origin clinically. Digital subtraction angiography can determine the precise site and type of aneurysm. In view of the high incidence of complications, early surgical treatment is recommended.

\section{Introduction}

Aneurysms of the subclavian artery and its branches are rare. Dent et al. ${ }^{1}$ in a series of 1,488 atherosclerotic aneurysms detected only two cases of subclavian artery aneurysms. Aneurysms of the inferior thyroid artery are still rarer. One presented to us as a clinically interesting problem.

\section{Case report}

A 40 year old male patient was admitted with the complaint of swelling in the right supraclavicular region for 5 years. It was a painless swelling of insidious onset, gradually increasing in size. There was no tingling and numbness in the right arm or any symptoms of exercise intolerance. There was no history of diabetes, hypertension, trauma or similar swelling in any other part of the body.

Examination revealed a $8 \times 6 \mathrm{~cm}$ soft compressible swelling in the right supraclavicular region with feeble pulsations (Figure 1). A palpable thrill and a systolic bruit on auscultation were present. His pulse rate was 78 /minute and blood pressure was $120 / 78 \mathrm{mmHg}$. All peripheral pulses were normal; the radial pulses were equal and synchronous, and there was no difference in blood pressure in the arms. All the haematological investigations were in the reference range and serological tests for syphilis were negative. $X$-ray of the neck showed no cervical rib. A clinical diagnosis of aneurysm involving the right subclavian artery was made. Digital subtraction angiography showed aneurysm of the right inferior thyroid artery (Figure 2). The right subclavian artery was normal.

At operation, a $6 \times 4 \mathrm{~cm}$ pulsatile mass was found arising from the right inferior thyroid artery.

Correspondence: Professor M.C. Misra, M.S. Accepted: 8 November 1993
The right transverse cervical and suprascapular arteries were arising proximal to the aneurysmal sac from the thyrocervical trunk. The trunks of the brachial plexus were lying behind the aneurysmal sac. The aneurysm was excised after proximal and distal ligation. There was no thrombus in the sac. The postoperative course was uneventful and the patient was discharged on the fifth postoperative

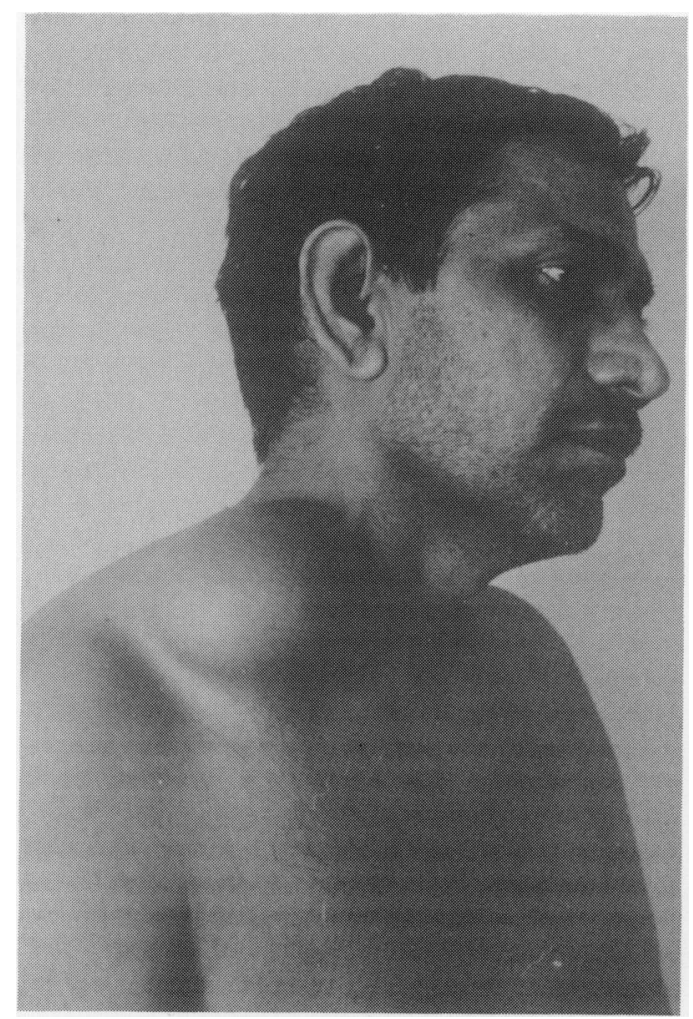

Figure 1 A clinical photograph showing a swelling in the right supraclavicular region. 


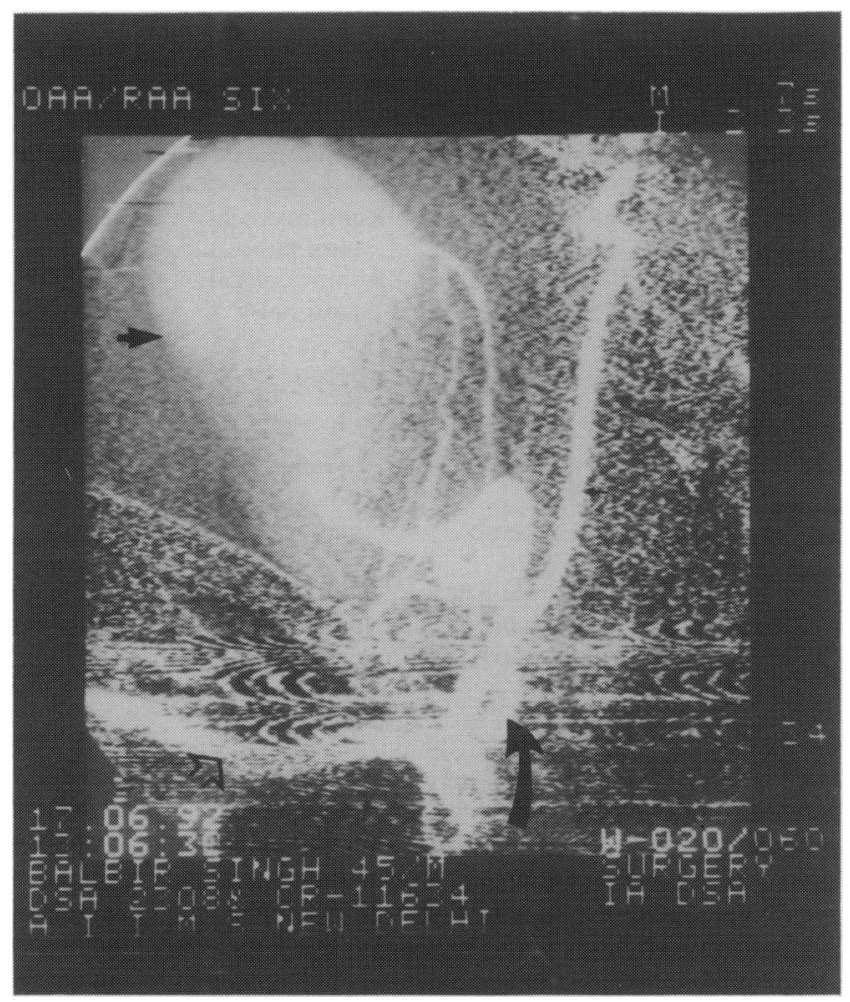

Figure 2 Digital subtraction angiography showing the aneurysm (straight larger arrow) arising from the right inferior thyroid artery. The right subclavian artery (open arrow), vertebral artery (smaller arrow) and thyrocervical trunk (curved arrow) are normal.

day. Histopathological examination revealed degenerative changes of the elastic tissue of the media of the artery.

\section{Discussion}

Aneurysms involving small peripheral arteries are very rare. Only seven cases of aneurysm ${ }^{2-6}$ of the inferior thyroid artery and two cases of aneurysm of thyrocervical trunk ${ }^{6,7}$ have been previously reported. With the present case, there are a total of ten reported cases of aneurysm involving the thyrocervical trunk or its inferior thyroid branch and their salient features are analysed in Table I.

Four of these cases presented as asymptomatic swellings in the neck. ${ }^{6,7}$ Two patients had a cervical swelling which was discovered incidentally on physical examination. ${ }^{6}$ The remaining four patients presented with symptoms such as hoarseness of voice $^{2,3,5}$ respiratory distress ${ }^{3,4}$ or dysphagia. ${ }^{2}$ Clinical examination may reveal a pulsatile or non-pulsatile swelling in the supraclavicular region $^{6,7}$ (six cases). More medially located swellings are often considered to be of thyroid origin ${ }^{3,5}$ and, preoperatively, an aneurysm is not suspected. In only six patients (including ours) was the diagnosis made preoperatively using arteriography ${ }^{6,7}$ and all six of these had swelling in the supraclavicular region. In two patients the diagnosis was made at surgery. ${ }^{2,5}$ In the remaining two, diagnosis was made during pathological examination of the excised specimen ${ }^{2}$ in one and at postmortem examination ${ }^{3}$ in the other.

Peripheral arterial aneurysms are usually atherosclerotic, traumatic, mycotic or due to angiitis or syphilis. All the reported cases have been true aneurysms. In three cases there was evidence of atherosclerosis. ${ }^{6,7}$ In one case there was no abnormality in the wall except for thinning of the intima. ${ }^{5}$ In six cases $^{2-6}$ (including the present case) degenerative changes, especially of the media have been noted and one of these was a primary dissecting aneurysm. ${ }^{4}$ Degenerative changes in the media have been noted in large vessels in Marfan's syndrome. No systemic features suggestive of this syndrome have been noted in any of these cases. Hypertension was recorded in two patients and may have been a contributory factor in the pathogenesis of the aneurysm. ${ }^{2,6}$ 
Table I Salient features of all reported cases of aneurysm of the thyrocervical trunk and the inferior thyroid artery

\begin{tabular}{|c|c|c|c|c|c|c|}
\hline $\begin{array}{l}\text { Subject } \\
\text { no. }\end{array}$ & Reference & Presentation & $\begin{array}{l}\text { Preoperative } \\
\text { diagnosis }\end{array}$ & Complication & Treatment & Outcome \\
\hline 1 & Doumanian $^{2}$ & $\begin{array}{l}\text { Hoarseness of } \\
\text { voice }\end{array}$ & $\begin{array}{l}\text { Mass at the } \\
\text { thoracic inlet }\end{array}$ & $\begin{array}{l}\text { Rupture, vocal } \\
\text { cord palsy }\end{array}$ & Excision & Successful \\
\hline 2 & Habib $^{3}$ & $\begin{array}{l}\text { Respiratory } \\
\text { distress and } \\
\text { dysphagia }\end{array}$ & Thyroid swelling & $\begin{array}{l}\text { Rupture, vocal } \\
\text { cord palsy }\end{array}$ & $\begin{array}{l}\text { No definite } \\
\text { surgery }\end{array}$ & $\begin{array}{l}\text { Died due to } \\
\text { intratracheal } \\
\text { rupture }\end{array}$ \\
\hline 3 & Golby $^{4}$ & $\begin{array}{l}\text { Acute } \\
\text { respiratory } \\
\text { distress }\end{array}$ & None & Rupture & $\begin{array}{l}\text { Emergency } \\
\text { excision }\end{array}$ & Successful \\
\hline 4 & Mashiah $^{5}$ & Hoarseness & Thyroid swelling & $\begin{array}{l}\text { Hoarseness of } \\
\text { voice }\end{array}$ & Excision & Successful \\
\hline 5 & Ketonen ${ }^{6}$ & $\begin{array}{l}\text { Swelling in the } \\
\text { neck }\end{array}$ & $\begin{array}{l}\text { Aneurysm of } \\
\text { inferior } \\
\text { thyroid artery }\end{array}$ & None & Excision & Successful \\
\hline 6 & Ketonen $^{6}$ & $\begin{array}{l}\text { Incidental } \\
\text { discovery }\end{array}$ & $\begin{array}{l}\text { Aneurysms of } \\
\text { thryocervical } \\
\text { trunk }\end{array}$ & None & Excision & Successful \\
\hline 7 & Ketonen $^{6}$ & $\begin{array}{l}\text { Swelling in the } \\
\text { neck }\end{array}$ & $\begin{array}{l}\text { Aneurysm of } \\
\text { inferior } \\
\text { thyroid artery }\end{array}$ & None & Excision & Successful \\
\hline 8 & Ketonen $^{6}$ & $\begin{array}{l}\text { Incidental } \\
\text { discovery }\end{array}$ & $\begin{array}{l}\text { Aneurysm of } \\
\text { inferior } \\
\text { thyroid artery }\end{array}$ & None & Excision & Successful \\
\hline 9 & Karangia $^{7}$ & $\begin{array}{l}\text { Loud bruit in } \\
\text { the neck }\end{array}$ & $\begin{array}{l}\text { Aneurysm of } \\
\text { thyrocervical } \\
\text { trunk }\end{array}$ & $\begin{array}{l}\text { Compression of } \\
\text { lower segments } \\
\text { of brachial } \\
\text { plexus causing } \\
\text { pain and } \\
\text { paraesthesia }\end{array}$ & Excision & Successful \\
\hline 10 & Present case & $\begin{array}{l}\text { Swelling in the } \\
\text { neck }\end{array}$ & $\begin{array}{l}\text { Aneurysm of } \\
\text { inferior } \\
\text { thyroid artery }\end{array}$ & None & Excision & Successful \\
\hline
\end{tabular}

The natural history of the untreated aneurysm is not available in any case. Six of the patients were operated on soon after the diagnosis was made. Complications were noticed at presentation in the remaining four and, in three of these, spontaneous rupture of the aneurysm had occurred. Rupture of the aneurysm is a serious complication with grave consequences which include vocal cord paralysis, ${ }^{2,3}$ respiratory distress ${ }^{4}$ necessitating tracheostomy and oesophageal compression. ${ }^{2,3}$ One patient died due to intratracheal rupture of the aneurysm. ${ }^{3}$ All

\section{References}

1. Dent, T.L., Lindenauer, S.M., Ernst, C.B. \& Fry, W. Multiple arteriosclerotic arterial aneurysms. Arch Surg 1972, 105: 338-344.

2. Doumanian, A.V., Soule, E.H. \& Ellis, F.H. Ruptured aneurysm of inferior thyroid artery with paralysis of vocal cord. Mayo Clin Proc 1959, 34: 303-304.

3. Habib, M.A. Fatal haemorrhage due to rupture of inferior thyroid artery aneurysm. J Laryngol Otol 1977, 91: 437-440.

4. Golby, M.G.S. \& Kay, J. Primary dissecting aneurysm of the inferior thyroid artery. Br J Surg 1965, 52: 389-391.

5. Mashiah, A. \& Horowitz, N. Unusual presentation of inferior thyroid artery aneurysm. J Cardiovasc Surg 1985, 26: 602-604. the patients who underwent excision of the aneursym had excellent outcome with relief of symptoms. Mortality was reported in the only patient in whom surgery was not undertaken as the diagnosis was made only at postmortem. ${ }^{3}$

In view of the potentially dangerous complications as well as a relatively simple surgical procedure with no significant morbidity or mortality, we advocate a policy of operating on all these cases as soon as the diagnosis has been made.

6. Ketonen, P., Meurala, P.T., Mattila, S. \& Ketonen, L. Aneurysm of inferior thyroid artery and thyrocervical trunk. Report of four cases. Thoracic Cardiovasc Surg 1981, 21: 60-61.

7. Karangia, N.D. \& Boulter, P.S. Aneurysm of thyrocervical trunk. Acta Chirur Scand 1992, 158: 565-566.

8. Matsubara, J.S., Shionoya, I., Ban, Y. et al. Clinical considerations on peripheral arterial aneurysms. J Cardiovasc Surg 1974, 15: 548-553. 